\title{
Chapter 11 \\ Social Times, Reproduction and Social Inequality at Work: Contrasts and Comparative Perspectives Between Countries
}

\author{
Màrius Domínguez-Amorós, Leticia Muñiz, and Gabriela Rubilar
}

\begin{abstract}
If the focus is placed specifically on the problem of work and family, the daily life of people and their use of time are a main problem. This time is expressed in both freely available time, which is related to activities, and time of the productive and reproductive sphere. This chapter considers work in a broad sense and takes into account the sexual division of labour.

Specifically, this chapter will explore transformations in time use and social inequality in unpaid work. For this purpose, a comparative analysis of time-use surveys will be used, analysing the time spent, and the time dedicated to household chores in Chile, Argentina, Uruguay and Spain. From an analytical viewpoint, the analysis will place social reproduction at the centre of the socio-economic system, showing that the economic crisis has affected women and men differently, and that in both Europe and Latin America the family pattern is being replaced by a dominant family model of a male provider and a double presence of women. The largescale incorporation of women into the labour market has emphasised the role that women assume in the domestic sphere perpetuating gender segregation in employment and in domestic and care work.
\end{abstract}

Keywords Gender inequalities - Social times - Productive and reproductive work · Sexual division of labour $\cdot$ Europe $\cdot$ Latin America

\footnotetext{
M. Domínguez-Amorós ( $\square)$

Bienestar, comunidad y control social, Universitat de Barcelona, Barcelona, Spain e-mail: mariusdominguez@ub.edu

L. Muñiz

Instituto de Investigaciones en Humanidades y Ciencias Sociales, Universidad Nacional de La Plata,

La Plata, Argentina

e-mail: 1munizterra@conicet.gov.ar

G. Rubilar

Universidad Católica de Chile, Escuela de Trabajo Social, Santiago, Chile

e-mail: grubilad@uc.cl
} 


\subsection{Introduction}

The aim of this chapter is to present a comparative analysis of time use and social inequality in the distribution of non-paid and care work in homes. In a context where the more traditional role of a single provider (male breadwinner/housewife household) is being replaced by the two-income model, the interest lies in analysing how strategies have been modified in relation to the contributions made in terms of time and work by the men and women that form households. Furthermore, the present work contributes to the comparative studies addressing societies that have been identified as familarist such as Argentina, Chile, Uruguay, and Spain.

The analysis of time, as an essential dimension of the organisation of society, serves to explore a large number of social behaviours, dynamics and habits; as well as social inequality processes according to people's life experiences, goals and priorities.

In relation to these social inequality processes, the elimination of economic inequalities continues to be a key element, with women's access to the labour market being considered as one of the main mechanisms to overcome said inequalities. In this regard, although there has been unquestionable progress in the participation and integration of women in paid work (higher activity and employment rates, improved education and qualification levels, increasing presence in certain occupations and activities, etc.), it has not been possible to transform a labour market that continues to display a clear predisposition towards gender inequality, penalising the specificities of the majority of women, undervaluing their skills and perpetuating situations of segregation, vulnerability and dependency, creating new obstacles and new forms of inequality (Gálvez and Rodríguez-Madroño 2011).

The elements, processes and dynamics at play behind the perpetuation of work inequality between women and men are diverse, and they must be understood in the framework of specific contexts and dynamics. But, evidently, one of the fundamental reasons is the unequal distribution of time and responsibilities in relation to domestic and care work ${ }^{1}$. Labour and economic inequality and the inequality of domestic and care work are processes that mutually reinforce each other.

In this regard, the research undertaken since the 1980s, especially from feminist approaches, has underscored the essential relevance of the study of "times generating reproduction" (times necessary for life: care, affection, relationships, leisure, ...) to highlight power relations and gender inequalities, and challenged a view focused on the "commodified time" of the (dominant) economy (Carrasco 2013).

If it is considered that the logic of time spent on care is synchronic, discontinuous and defined by subjective aspects of daily experience (Domínguez 2020), it is

\footnotetext{
${ }^{1}$ The concept of domestic and care work is also a subject of debate, with different conceptualisations and approaches. In this work we will call it domestic and care work, following that set out by Bundlender (2010) who specifies: unpaid domestic work in the household (widely equivalent to domestic chores) and unpaid care work for people in the household.
} 
essential to explore the possibilities of coordinating paid work times with other times of life: relationships, care, family, cultural activities, leisure, etc.

Without a doubt, unpaid domestic and care work, consistent with the life cycle, is an essential factor that contributes to the welfare of people, their families and societies. Its aim is to guarantee the health and welfare of all people, whether women or men (those providing care and those receiving care).

Thus, considering families as providers of welfare and the main - although hidden-role of a large part of the work performed by women helps to identify the sexual division of work (the division between paid work and unpaid domestic and care work) and the different use of time as the mainstay of the economic, social and political subordination of women (Aguirre 2015; Ferrant et al. 2014; Carrasco and Domínguez 2011; Folbre 2008; Arriagada 2007).

As regards work times, several research projects demonstrate the tendency towards convergence between men and women in their dedication to work: the increase in the participation of women in paid work and a decrease in unpaid work, as well as a higher presence of men in domestic and care work. This convergence is slow in a context in which the sexual division of work continues and persists, reproducing the almost exclusive assignment of reproductive and care work to women, without entailing shared responsibilities in households (Kan et al. 2011; Bianchi et al. 2000; Gálvez et al. 2010; Kan and Gershuny 2010; Sayer 2010; Treas and Drobnic 2010; Hook 2006; Gershuny 2000; Moreno 2009; Marini and Shelton 1993).

The presence of women in both jobs and, therefore, their higher work load and consequent reduced spare time, time for themselves and time for social and political participation, limits their options of joining the labour market, and perpetuates power relations and gender order, affecting their welfare and quality of life (Cepal 2017b, 2016; Ferrant et al. 2014; Calero et al. 2015). This high cost, resulting from the social response to caring needs and the social organisation of care, explains the social inequality processes existing in the labour market: activity rates, situations of underemployment, vertical segregation, salary gap, etc. In addition, there are clear mechanisms of internal inequality between women since this situation is more costly in those women with fewer resources for employment (education level and previous work trajectories), with greater demands for care in households (presence of minors, and elderly, infirm or disabled adults) and with fewer possibilities of redistributing the care needs of the household (to public or private services outside of the home, or to solidarity networks) (Rodríguez 2015).

Under this system, the debate surrounding productive and reproductive work acquires new meanings when the demographic, social, economic and political changes registered in contemporary societies are analysed. More specifically, and as pointed out above, the position of women in the productive sphere and their economic participation in the labour market is related to the way in which issues related to reproductive work are resolved individually and socially and their association with the commodification processes of care work (Izquierdo 1998; Torns 2008), the return of care to the home and care chains (Hochschild 2002; López Gil and Pérez Orozco 2011; Mora and Medina 2011). Thus, the rediscovery of care work times and its consolidation as a subject of study has occurred against the background of 
the 'care crisis' (Pérez Orozco 2006) which serves to analyse the different ways of organising care work and the (re)configurations of the traditional welfare actors (state, market and families) to respond to new needs and demands ${ }^{2}$.

This chapter analyses the relation between welfare and social times, considering some debates on the gender perspective, the social division of work and its implications on social inequality. Considering that productive work has to date been the dominant category from which class and social mobility studies have been developed, in this chapter the problem of reproductive work is included to highlight that this is a determining factor in the social position of individuals. Bearing in mind, therefore, that, in social reproduction, the reproductive sphere (specifically domestic and care work) has traditionally been subordinate to the productive sphere, it is essential to recover its importance insofar as it directly affects the position of individuals in the labour market.

To do so, we propose performing an empirical analysis that reveals the social inequality processes in work times (productive and reproductive); through a comparative analysis of time-use surveys, analysing the time spent on care work and the time dedicated to domestic household chores in dual-income heterosexual couples.

After this introduction, the chapter is structured in five sections. The first of these gives an account of some of the methodological considerations in the current debate on the conceptualisation and measurement of time use. Next, the most relevant contextual and macrosocial elements are presented, which help to obtain a comparative view of the countries being analysed. Specifically, the Gender Gap Index of the World Economic Forum and indicators related to gender ideology provided by the World Value Survey will be used. The fourth and fifth sections present a specific comparative analysis in relation to work times, reproduction and social inequality. More specifically, the factors explaining the gender gap in the distribution of unpaid domestic and care work will be analysed for households with dual-income heterosexual couples in Argentina, Chile, Spain and Uruguay. The chapter ends with some of the conclusions concerning social times, reproduction and inequality in work.

\subsection{Theoretical-Methodological Considerations}

As has been pointed out, the large majority of studies, especially economic studies, have provided a partial and incomplete view of work since they have focused on paid work (productive), disregarding unpaid activities that generate welfare (reproductive work) and rendering their contribution and relation with other daily activities invisible.

Since the 1970s, vast theoretical and methodological work has been developed in several disciplines, providing empirical evidence about the contribution of domestic

\footnotetext{
${ }^{2}$ Although the importance of the analysis of welfare states, care regimes and public policies is unquestionable, it will not be developed in this chapter, since they are the subject of other chapters in this book.
} 
and care work to welfare, and to the reproduction and sustainability of human life (Carrasquer 2013). On an empirical level, time-use studies have become an ideal quantitative methodology to collect information about different work times; to show times as a key element in the study of inequalities between women and men (Durán 1997); and to tackle time distribution, in the different activities, as an important aspect in the welfare of the population, reflecting inequalities in the access to resources and affecting opportunities and capabilites (Aguirre 2015; Aguirre and Ferrari 2014; Cepal 2017a; Batthyány 2015a; Aguirre and Ferrari 2014; Carrasco and Domínguez 2014; Durán and Milosavijevic 2012; Antonopoulos and Hirway 2010; Eurostat 2008). Furthermore, this type of study helps to formulate public policies that respond to social care needs through joint responsibility and the equal distribution of care work in households, as well as advocacy actions in this respect with implications on policies or possibilities of reforms (Rajivan 1999).

This type of empirical work contributes towards verifying the need to broaden the operational definition of the theoretical constructs of work and times, incorporating measures that include the multi-dimensional nature of these concepts and the dualities affecting them.

This section gives an account of some of the relevant challenges in the current debate, both from theoretical-conceptual approaches and from methodological approaches, which have developed around the measurement and empirical studies of times and their inequalities.

The time-use methodology, and in particular, time-use surveys influenced debates which, from a critical feminist perspective, affected the actual conceptualisation of time. Time in this case is understood as invariable, homogeneous, independent of context and compared to a commodified money-time which is dominant, recognised and valued. Furthermore, it is a time that reflects the structures of power and of capitalist and patriarchal relations (Adam 2004; Carrasco 2016, 2005; Carrasco and Recio 2014; Domínguez et al. 2019; Ramos 2011, 1990; Torns 2001, 2004).

As a clear example of this, the chief methodological trend can be situated in this type of studies: the countable approach to care work (or to part of it: domestic and family) calculated and measured in reference to paid work time; valued and recognised time, around which the other times, essentially care work time, must be organised.

This type of approach has highlighted some important limitations in the study of times, setting out highly relevant theoretical-methodological challenges. Most notable of these is the multi-dimensional understanding of domestic and care work. This means both the need to specify the implicit conception of time underlying the measurement; and to combine the quantitative-countable measurements of time use with those that show the subjective aspects involved in the caring relationship and which help to obtain information about the consequences of the interrelation of daily times. Notable among these are: incorporating measures that highlight the emotional dimension of care; redirecting the interest towards the protagonist subject providing the care; and adding the assessment the protagonists make of their own activities, as well as the dynamic and context in which they develop them. 
In relation to the subjective aspects of daily life, key to understanding the social definitions of time, its symbolic structures and hierarchical relations, it is particularly relevant to tackle the social norms, values and imaginaries that reproduce and legitimise female protagonism in care time and the heterogeneity of practices and world views of care (Almeda et al. 2016; Castelló 2011; Domínguez et al. 2019; Jiménez-Martín and Vilaplana 2012; Martínez-Buján 2014; Moreno et al. 2013; Ortiz-Monera et al. 2016; Rogero 2010; Tobío 2012).

In this regard, the World Value Survey (WVS) developed by the Institute for Social Research at the University of Michigan falls under this type of approach. At present, the seventh wave of surveys, to be finalised in 2019, is being conducted with 80 countries and with a particular emphasis on the study of emerging topics and perspectives that entail a change in values. Of particular significance in this survey are the questions comparing the values of the current generation with the values of future generations as regards society values, the role of women, conceptions of the family, views on work and public policies.

In Latin America, the work of Latinobarómetro is noteworthy. It conducts an annual study of public opinion which analyses the development of democracy, economy and society as a whole, using public opinion indicators which measure attitudes, values and behaviours. The results of this study, based on surveys $(20,000)$ applied in 18 countries from Latin America from 1995 (beginning of the measurements) to date, help to establish comparisons between countries from the region and within each country.

The second theoretical-methodological challenge in relation to the approach towards times lies in the difficulty perceiving and defining care time by the people themselves and their lower implementation and specification in the majority of statistical operations. In this regard, we call for greater effort in detailing and contextualising questions on time use when caregiving (Bundlender 2010; Ramos 2011) since the more detailed and contextualised the activities specified, the broader the time registered for these activities.

The third challenge, closely related to the two above, is related to the difficulty perceiving and defining the time dedicated to management tasks, maintenance, organisation and responsibilities of care work; and passive caregiving time, a time of continuous availability, of continuous support; a hidden time that reveals the experiences lived - the energy and fatigue-and the specific conflicts-tensions and conflicts - of time and timetable organisation.

Fourth, recovering the structure of the different times and their time sequences (synchrony, simultaneities and discontinuities of the logic of paid work time and caregiving time), is proving to be an important line of work in a context in which labour flexibility guidelines are gaining ground. In this context, contradictions emerge between both time logics and their gradual desynchronization which is a great burden on women in a situation of double presence (Lewis and Weigert 1992).

Lastly, the measurement of times must recognise inequality processes, highlighting the suitability of opening up the analysis to the great absentee of care work, the male gender, and to the persistence of other axes of inequality and social stratification in caregiving time. Several studies verify the persistence and emergence of 
social inequalities on the grounds of gender, origin, ethnicity and social class which emerge firmly in relation to the migratory processes linked to caregiving in global capitalism (Aulenbacher et al. 2018; Fraser 2016; Goñalons-Pons 2015; Kofman and Raghuram 2015; Lutz 2017; Martínez-Buján 2014; Moreno et al. 2013; Oso and Parella 2012; Parella 2003).

In relation to the time-use data collection tools, in European countries, the methodological standardisation in time-use studies meant we could avail of both the database of the Multinational Time Use Study (MTUS) for 25 countries, and the Harmonised European Time Use Survey (HETUS) harmonised since 2005 with the European time use guidelines, from the Statistical Office of the European Union (EUROSTAT 2008). Specifically, to guarantee a higher level of data quality and comparability between countries, the surveys, formats of the time-use diaries, procedures to collect data and the list of shared activities are standardised. The time-use diary is a self-administered diary with set 10-min intervals to fill in on the randomly designated diary days.

In turn, in recent years, the development of time-use surveys in the majority of Latin American countries, and the studies sponsored by the United Nations Economic Commission for Latin America and the Caribbean (ECLAC), and national statistical institutes, have generated relevant information to highlight gender inequalities in the time dedicated to unpaid domestic and care work (Batthyány 2015a; Calero et al. 2015; Rodríguez 2015; Aguirre 2015; Aguirre and Ferrari 2014; Durán and Milosavijevic 2012; Bundlender 2010; Espejo et al. 2010; Arriagada 2007). Nevertheless, the comparative empirical work in Latin America is still weak, scarce and discontinuous. These include the works of Amarante and Rossel (2017), with data from Colombia, Mexico, Peru and Uruguay; Campaña et al. (2017), with their study on time-use data from Mexico, Peru and Ecuador; Bundlender (2010), with his analysis of Argentina, Nicaragua, India, South Korea, South Africa and Tanzania; and Antonopoulos (2008), with time-use surveys from Bolivia, Guatemala, Mexico, Nicaragua and other countries from the OCDE.

\subsection{General Comparative Overview of the Countries}

On a comparative level in Europe, empirical evidence shows that, while a reduction in gender differences can be observed in time-use over the past 50 years, as a result of more women dedicating their time to paid work and more men dedicating their time to domestic and care work, gender segregation in relation to domestic chores persists. Women continue to do the more routine activities while men focus on doing the more flexible and less rigid ones (Moreno 2015).

Among the factors explaining this reduction, some are related to the second demographic transition: the widespread access of women to education, the higher participation of women in the labour market and the consolidation of social rights associated with the goal of equal opportunities (Sayer 2010). In addition to this 
Table 11.1 Participation time and participation rate in the main activity by sex

\begin{tabular}{|c|c|c|c|c|c|c|}
\hline \multirow[b]{2}{*}{$\begin{array}{l}\text { Country \& } \\
\text { Participation } \\
\text { time/rate }\end{array}$} & \multicolumn{3}{|l|}{ Females } & \multicolumn{3}{|l|}{ Males } \\
\hline & $\begin{array}{l}\text { Employment, } \\
\text { related } \\
\text { activities and } \\
\text { travel }\end{array}$ & $\begin{array}{l}\text { Household } \\
\text { and family } \\
\text { care }\end{array}$ & $\begin{array}{l}\text { Leisure, } \\
\text { social and } \\
\text { associative } \\
\text { life }\end{array}$ & $\begin{array}{l}\text { Employment, } \\
\text { related } \\
\text { activities and } \\
\text { travel }\end{array}$ & $\begin{array}{l}\text { Household } \\
\text { and family } \\
\text { care }\end{array}$ & $\begin{array}{l}\text { Leisure, } \\
\text { social and } \\
\text { associative } \\
\text { life }\end{array}$ \\
\hline \multicolumn{7}{|l|}{ Spain } \\
\hline Time & $6: 43$ & $4: 36$ & $4: 53$ & $7: 55$ & $2: 36$ & $5: 44$ \\
\hline Rate & 29.5 & 93.0 & 97.7 & 40.7 & 75.9 & 97.7 \\
\hline \multicolumn{7}{|l|}{ France } \\
\hline Time & $6: 13$ & 4:04 & $4: 54$ & $7: 21$ & $2: 53$ & $5: 30$ \\
\hline Rate & 30.5 & 93.6 & 97.7 & 41.4 & 80.5 & 97.0 \\
\hline \multicolumn{7}{|l|}{ Italy } \\
\hline Time & $6: 43$ & 5:09 & $4: 35$ & 8:04 & $2: 22$ & $5: 26$ \\
\hline Rate & 25.8 & 92.7 & 97.9 & 46.5 & 68.3 & 98.5 \\
\hline \multicolumn{7}{|l|}{ Finland } \\
\hline Time & $6: 50$ & $3: 41$ & $5: 44$ & $7: 41$ & $2: 32$ & $6: 33$ \\
\hline Rate & 30.2 & 96.0 & 99.6 & 36.1 & 90.7 & 99.0 \\
\hline \multicolumn{7}{|c|}{ United Kingdom } \\
\hline Time & $6: 27$ & $3: 50$ & $5: 03$ & $7: 15$ & $2: 27$ & $5: 40$ \\
\hline Rate & 32.3 & 95.2 & 98.4 & 43.8 & 87.7 & 97.5 \\
\hline
\end{tabular}

Participation Time per day (Partic. Time, hh:mm) and Participation Rate (Partic. Rate, \%). European countries analysed

Source: author's own elaboration based on Harmonised European Time Use Surveys (HETUS), Eurostat, 2010

process, globalisation processes and transnational migrations may indicate a third movement.

Table 11.1 provides a first approach to the participation and time dedicated by women and men to paid work and domestic and care work according to the time-use surveys in European countries.

As regards European data, the time gap indicates that women, apart from in France, work more (higher overall work load) than men on a typical day: from 18 min in Finland, 35 and 48 min respectively in the United Kingdom and Spain, to $1 \mathrm{~h} 26 \mathrm{~min}$ in Italy.

The analysis according to the type of work verifies that women dedicate less time than men to paid work (from $48 \mathrm{~min}$ in the United Kingdom to $1 \mathrm{~h} 21$ min per day in Italy). This lower participation in the labour market does not offset their greater dedication to domestic and care work: they dedicate slightly more than $1 \mathrm{~h}$ a day in France and Finland, 1 h 23 min more in the United Kingdom, 2 h in Spain and nearly $3 \mathrm{~h}$ per day in Italy.

Thus, as regards unpaid and care work, it has been verified that women register higher participation and time than men in reproductive work and that it is precisely this unequal distribution which, among other elements, restricts the participation of women in the labour market, conditioned by the assignment of women to domestic and care work. 
Table 11.2 Time dedicated to total work—paid and unpaid—of the population aged 15 and above, per sex (in weekly hours)

\begin{tabular}{l|l|l|l|l|l|l}
\hline & Unpaid work & Paid work & \multicolumn{2}{l}{ Total work time } \\
\hline & Females & Males & Females & Males & Females & Males \\
\hline Argentina & 43.0 & 17.6 & 15.6 & 34.0 & 58.5 & 51.6 \\
\hline Brazil & 23.6 & 5.9 & 19.9 & 37.0 & 43.4 & 42.9 \\
\hline Chile & 42.4 & 19.4 & 19.8 & 34.6 & 62.2 & 54.0 \\
\hline Mexico & 54.1 & 19.5 & 20.5 & 44.9 & 74.6 & 64.4 \\
\hline Uruguay & 36.3 & 16.0 & 21.8 & 36.7 & 58.1 & 52.7 \\
\hline
\end{tabular}

Latin American countries analysed

Source: author's own elaboration. United Nations Economic Commission for Latin America and the Caribbean (ECLAC)

Mexico: INEGI, National Time-use Survey, 2014; Chile: INE, National Time-use Survey, 2015; Uruguay: INE, Uruguay Time-use Survey, 2013; Argentina: Module in the Annual Urban Household Survey, 2013; Brazil: Pilot survey in five states in Brazil, 2012

The most notable results of the Latin American studies are convincing and consistent with the evidence from other international time-use surveys (Rodríguez 2015), displaying the higher overall work load of women, the increase in the gender gap and the incidence of socioeconomic stratification (Cepal 2017a, 2016; Batthyány 2015a; Calero et al. 2015; Rodríguez 2015; Arriagada 2007).

The results in Table 11.2 show the greater overall work load of unpaid work and total time worked of women compared to men in the five Latin American countries analysed, widening the gender gap in those countries with a more unequal structure such as Mexico and Chile (UN 2005) ${ }^{3}$.

From 2000 onwards, transnational comparative studies have emphasised the relevance of completing the micro analyses with macrosocial approaches to understand the division of unpaid domestic and care work in the household (Amarante and Rossel 2017; Yu and Xie 2014; Lachance-Grzela and Bouchard 2010; Hook 2006; Fuwa 2004). Five essential dimensions are considered: (1) the level of gender equality; (2) the economic development; (3) the social and demographic structure; (4) the state policies related to gender equality and the welfare state; and (5) the cultural norms (Batthyány 2015b; Blofield and Martínez 2014; Lewis 2010; Arriagada 2007).

As regards the first dimension, gender equality is analysed by examining the opportunities, inequalities and discriminations on the grounds of gender in economic, work-related, social and political spheres. In this regard, as indicated by some research (Ferrant et al. 2014; Rizavi and Sofer 2010), in those countries in which the gender gap is wider, the role of the woman is usually limited to domestic and reproductive functions.

If the Gender Gap Index from the World Economic Forum (2018), Table 11.3, is used as a reference, it can be observed that the European countries have higher overall

\footnotetext{
${ }^{3}$ In the case of Brazil, it is important to highlight the undervaluing of the data referring to unpaid work; the data reveal approximately half the dedication of the other countries.
} 
Table 11.3 Index of the Gender Gap of the World Economic Forum and sub-indexes by dimensions

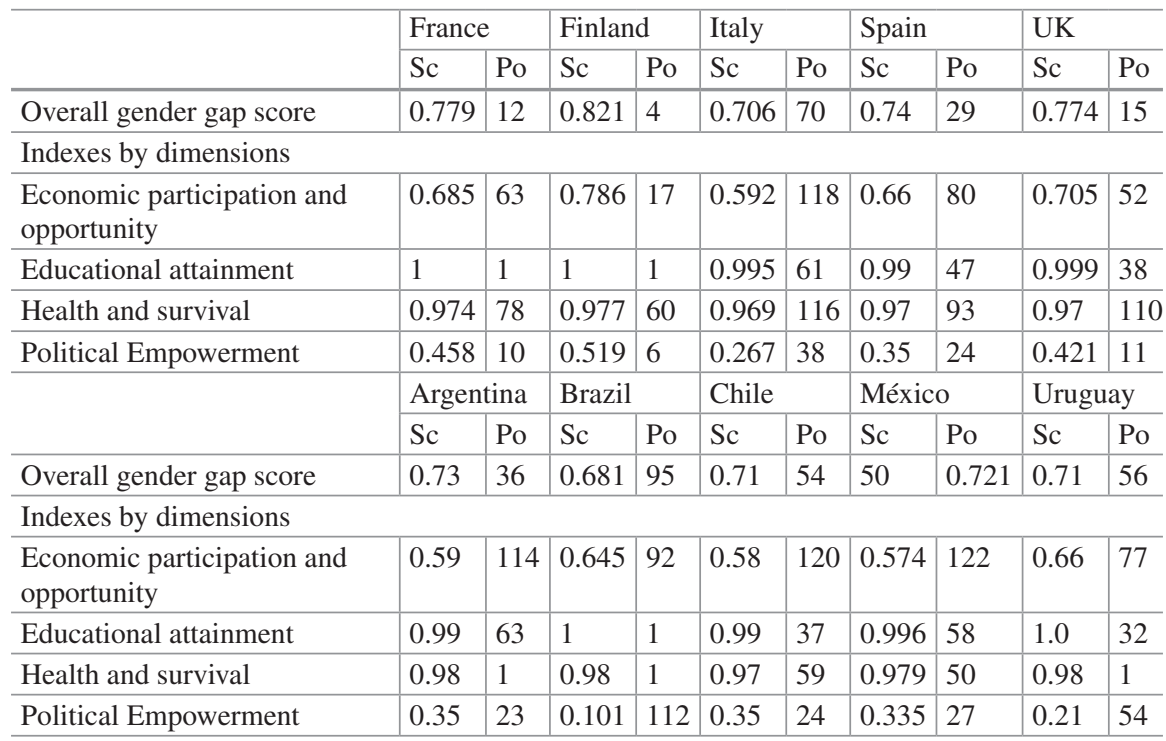

Countries' scores (Sc) and positions (Po) in the ranking, 2018. European and Latin American countries analysed

The maximum value in the indices is 1 (parity) and the minimum 0 (disparity)

Source: author's own elaboration. World Economic Forum (2018)

gender equality than the Latin American countries. The exception is Italy which has the most disadvantaged position in the ranking of countries, alongside Brazil.

Furthermore, beyond the small differences in the positions occupied in the ranking, the indices in education and health-survival dimensions are high both in Latin American countries and in European countries (between 0.97 and 0.98) showing higher equality in both dimensions.

However, the most notable differences can be observed in the data relating to economic participation and opportunity, and political empowerment where Spain and, mainly Italy, reach similar values to the Latin American countries. These data are relevant if it is considered that the incorporation of women into the labour market and their economic and financial independence afford women better negotiation skills for an equal division of unpaid work (Amarante and Rossel 2017; Yu and Xie 2014; Lachance-Grzela and Bouchard 2010; Fuwa 2004). Therefore, the gender gap in the participation, salaries and presence of women in high socio-professional categories highlights this key aspect.

The detailed analysis of the results of the "economic participation and opportunity" dimension reveals that the participation rate of women in 2018 shows considerable differences between the regions that reach 12 percentage points between the countries with highest and lowest female labour participation; and within regions, since while in Europe a difference of 6 percentage points can be observed (48\% in Finland compared to $42 \%$ in Italy), in Latin America this difference exceeds 9 percentage points. Thus, in Latin America, countries from the Southern Cone 
(Argentina, Chile, Brazil and Uruguay) share a rate of more than $40 \%$ unlike Mexico, which can be partially explained by the fact that they are less traditional countries in their gender ideologies, and they have a greater presence of formalised jobs compared to informal employment (56.8\% in the case of women in Mexico).

In turn, the part-time employment of men and women for 2018 shows significant differences between the participation rates of both sexes for all the countries considered in this study. In Latin America, Mexico is the country with the lowest part-time employment rate for men (17\%), while Argentina is the country with the highest rate at $27 \%$ and also the highest female rate $(51.3 \%)$ in the region. Mexico has the lowest female rate $(33.2 \%)$, as a result of a large sector of informal work.

In Europe, greater heterogeneity can be observed in the distribution of part-time employment across countries, with Spain being the country with the lowest male rate $(21.7 \%)$ and Finland the country with the highest rate $(36.7 \%)$. The United Kingdom has the highest female rate at 57\% and Spain has the lowest female rate at 40.9\%. This distribution also highlights that while in Argentina the part-time employment rate is high, although different for men and women, in Spain said rate is low for both sexes.

This information is relevant as it illustrates significant differences between the countries which are associated with the welfare and gender models affecting them; the reasons for working part-time can be personal or structural, in other words, they can refer to the decision or need to work part-time for personal reasons (because of studies or reproductive responsibilities) or to the reduced contract hours applied by the employers, or to not finding a full-time position.

As regards political empowerment, in the countries analysed there is a quota law in the elections. For example, $40 \%$ in Spain and Chile (in the latter only in terms of female parliament candidates since 2017) and 30\% in Argentina. However, taking these same countries, equality in political representation is far from being attained since the percentage of women in the parliament is $42 \%, 39.1 \%$ and $38.9 \%$ in Finland, Spain and Argentina, compared to $15.8 \%$ in Chile and $10.7 \%$ in Brazil. Although the percentages change between the countries when analysing the percentage of female ministers: 4\% in Brazil, 17.4\% in Argentina, 30.8\% in Chile, 35\% in Uruguay and 38.5\% in Spain and Finland.

As regards economic development, the national income per capita in dollars (PPP) for 2018 estimated by the World Bank for the ten countries comprising the present research, shows a large difference both between the countries from Latin America and Europe and within regions. Thus, while Finland presents the highest income $(\$ 47,820)$, followed by the United Kingdom $(\$ 41,330)$ and France $(\$ 41,070)$, countries from the south of Europe have considerably lower incomes, both Italy $(\$ 33,560)$ and Spain $(\$ 29,450)$. On the contrary, in Latin America the differences between the countries with the highest and lowest income are not as vast, although significant differences can nevertheless be observed; Uruguay has the highest income at $\$ 15,650$, and Mexico has the lowest $(\$ 9180)$. Chile $(\$ 14,670)$, Argentina $(\$ 12,370)$ and Brazil $(\$ 9140)$ are in between.

Although briefly, it is of interest to give an account of the sociodemographic structure of the countries in terms of their demographic transitions and ageing trends, and their relation with care work, which have been especially visible in Latin 
America since the beginning of the 2000s. This evolution responds to the rapid reduction in fertility and the sustained decrease of mortality. "In the middle of the last century, the annual growth rate of the regional population was $2.8 \%$, while at present it is only 1.2\%" (Bárcena 2011).

Changes in the age structure of the population have major consequences on inequality in and between generations and on the analysis at hand in this research on reproductive and productive time.

Regarding the maternal mortality rate, significant differences can be observed between continents, since while none of the European rates reaches 10 out of 100,000, the Latin American rates exceed 50 out of every 100,000. These figures clearly show the effectiveness and reach of health policies, and the recognition of sexual and reproductive health rights. In addition, differences in the infant mortality rate are presented. Although the rates reduce if we compare them with the maternal mortality rate, there continue to be significant differences between continents. In Latin America the highest infant mortality rate is that of Brazil, standing at $13.2 \%$, followed by Mexico (11.5\%); compared to Chile (6.3\%), Uruguay (7\%) and Argentina (9.1\%). In Europe the highest infant mortality rate is $3.7 \%$ and the lowest is in Finland, standing at $1.9 \%$.

As regards fertility, it is important to point out that the differences reduce between continents since there is a general downward trend in the fertility rate and due to the ageing of the population. Thus, while none of the European countries exceeds a rate of 1.9 children per woman (France), others such as Spain hold the lowest fertility rate (1.3 children), and Latin American countries vary from 2.1 children in Argentina to 1.7 in Brazil.

From another perspective, if cultural norms are observed, an analysis of the indicators referring to the ideology and attitudes towards gender roles and stereotypes can be developed, using the World Values Survey (WVS) (Institute for Comparative Survey Research 2017), implemented homogeneously in all the countries studied (see Table 11.4).

The data show that, although gender inequalities continue to be forcefully expressed in gender values (ideologies, attitudes towards gender roles and stereotypes), some countries stand out beside others because of their specific perspectives in relation to some variables: in Finland it is considered that being a housewife is more satisfactory than having a paid job (82\%), in Italy and Chile it is maintained that in a context of scarce positions in the labour market men should be more entitled to employment $(39.8 \%$ and $41.9 \%)$, in Chile if the woman earns more than the man this can cause problems, $(66.2 \%)$ and in Brazil it is maintained that when mothers work their children suffer $(60.4 \%)$.

Lastly, although this chapter will not explore the state policies related to gender equality and the welfare state as they are the subject of specific chapters in this book, it is interesting to underscore the relevance of analysing whether the state acknowledges the existence of inequalities that call for different measures to be adopted according to sex to guarantee equality and the respect of human rightssuch as legislation on violence against women and affirmative actions such as quota systems for women's political participation-, as well as the implementation of labour policies based on equal opportunities and social policies supporting care (parental leave, flexible work hours, paid work at home). 
Table 11.4 Opinions on aspects related to the ideology of gender, by country. World Values Survey (percentage of answers expressing agreement with the statement or neutrality)

\begin{tabular}{l|l|l|l|l|l}
\hline & France & Finland & Italy & Spain & UK \\
\hline $\begin{array}{l}\text { When there is little work, men must have more } \\
\text { right to a job }\end{array}$ & 26.2 & 18.4 & 39.8 & 17.5 & 23.3 \\
\hline $\begin{array}{l}\text { If a woman earns more than her husband, this } \\
\text { will almost certainly create problems }\end{array}$ & - & - & - & 25.0 & - \\
\hline $\begin{array}{l}\text { When a mother does paid work her children } \\
\text { suffer }\end{array}$ & - & - & - & 28.5 & - \\
\hline $\begin{array}{l}\text { In general, men are better political leaders than } \\
\text { women }\end{array}$ & 20.7 & 18.7 & 17.9 & 11.5 & 17.8 \\
\hline $\begin{array}{l}\text { A university education is more important for a } \\
\text { boy than for a girl }\end{array}$ & 6.7 & 6.3 & 7.8 & 11.7 & 6.6 \\
\hline $\begin{array}{l}\text { Being a housewife is almost as satisfying as } \\
\text { having a paying job }\end{array}$ & 50.0 & 82.0 & 49.8 & 49.5 & 59.7 \\
\hline $\begin{array}{l}\text { When there is little work, men must have more } \\
\text { right to a job }\end{array}$ & 29.5 & 26.8 & 41.9 & 29.3 & 32.5 \\
\hline $\begin{array}{l}\text { If a woman earns more than her husband, this } \\
\text { will almost certainly create problems }\end{array}$ & 46.0 & 50.5 & 66.2 & 57.3 & 38.6 \\
\hline $\begin{array}{l}\text { When a mother does paid work her children } \\
\text { suffer }\end{array}$ & - & 60.4 & 37.8 & 43.6 & 37.4 \\
\hline $\begin{array}{l}\text { In general, men are better political leaders than } \\
\text { women }\end{array}$ & 27.5 & 28.4 & 28.2 & 23.0 & 9.1 \\
\hline $\begin{array}{l}\text { A university education is more important for a } \\
\text { boy than for a girl }\end{array}$ & 16.6 & 9.4 & 20.9 & 20.7 & 9.7 \\
\hline $\begin{array}{l}\text { Being a housewife is almost as satisfying as } \\
\text { having a paying job }\end{array}$ & 54.2 & 44.4 & 44.4 & 58.2 & 59.7 \\
\hline
\end{tabular}

Source: author's own elaboration based on the sixth wave of the World Values

Surveys. Argentina, 2013; Brazil, 2014; Chile, 2012; Finland, 2005; France, 2006; Italy, 2005; México, 2012; Spain, 2011; United Kingdom, 2005; and Uruguay, 2011. Inglehart et al. (eds.) (2014)

\subsection{Comparative Analysis of the Gaps in Domestic and Care Work}

This final part of the chapter presents a specific comparative analysis in relation to work times, reproduction and social inequality ${ }^{4}$. Specifically, and taking the previous sections as a reference, we will analyse the factors explaining the gender gap in the distribution of unpaid domestic and care work performed in their homes by dual-income heterosexual couples from Argentina, Chile, Spain and Uruguay. This will serve to further the comparative analysis of the individual and household

\footnotetext{
${ }^{4}$ The comparative empirical analysis presented is based on the research work published in Domínguez, M.; Muñiz, L.; Rubilar, G. (2019).
} 
factors explaining the unpaid work gap; and to interpret the differences between the countries according to socio-political and cultural contexts.

In this regard, and following the contributions of Aguirre (2003) who-based on the works of Sarraceno \& Sainsbury_-, classifies states as familarist (the responsibility of welfare falls to families and women) and as moving away from the family (domestic and care roles are drifting toward the state and the market), the countries examined in this section are characterised as familarist, following the Mediterranean welfare model (Martinez and Voorend 2013). Moreover, in those countries with this welfare regime and with a scarce public services network, there continues to be a sexual division of work in which women are in charge of caregiving and domestic work (as well as providing income) and men are essentially dedicated to bringing in money through paid work (Blofield and Martínez 2014; Gálvez et al. 2010; Geist 2005; Kan et al. 2011). Furthermore, it has been observed that the widest gender gaps in unpaid work occur in the population with greatest socioeconomic vulnerability, where gender representations are more traditional and the pathway to adulthood is marked by early motherhood, a higher number of children, low education levels and a precarious and interrupted work history (Rodríguez 2015; Batthyány and Scavino 2017).

Argentina, Chile and Uruguay are market-centred countries, which, depending on the type of government, have sought to create laws that facilitate a change towards more equal and less familarist models, with Chile being the most conservative (Midaglia and Antía 2017; Filgueira 2007; Bloflied and Martínez 2014). Uruguay has made greater progress in legislation in general and particularly in legislation associated with family care leave (Blofield and Martínez 2014), but care strategies and the use of time still shows a sustained familialism, in other words, a familialism with reticent options and support from the state (Scavino 2017).

In Spain, Moreno (2007) highlights familialism as an underlying normative benchmark in the collective social imaginary and in institutional practice, although in recent years policies aimed at promoting female employment have been developed (longer maternity and paternity leaves and the granting of child benefit, aimed at working mothers). However, the consequences of the economic downturn (2010) were met with "austerity" in economic politics (reduction of salaries and public expenditure) and the slowing down of equality policies, in the context of a neoliberal political project, with the predominance of equal opportunities policies (Salazar 2016; Bettio et al. 2012; Karamessini and Rubery 2014).

In this context, the analysis of the microsocial factors in the explanation of the gender gap in domestic and care work can be situated in three theoretical perspectives.

First, the availability of time, based on the human capital theory and Becker's family theory, which understands the division of unpaid domestic and care work as a rational allocation resulting from other demands on people's time. Thus, people from the household contribute to the different activities according to their specialised skills, productivity and expected benefits. Therefore, the greater amount of time dedicated by women to domestic and care work, with a lower dedication to paid work, would be a consequence of men's higher salaries, and women's specialisation in this work (Davis et al. 2007; Gershuny and Sullivan 2003; Bianchi et al. 2000; Greenstein 1996).

The second theoretical perspective is that of relative resources, or the theory of economic exchange, which places us in a negotiation process between the members 
of the couple, in which people's negotiating power depends on income, education and occupational prestige (Pinto and Coltrane 2009; Bernhardt et al. 2008; Knudsen and Wearness 2008; Mannino and Deutsch 2007; Fuwa 2004). Moreover, it is presumed that people will seek to minimise their time dedicated to domestic and care work, using any advantage of resources to better negotiate their absence from domestic and care work (Brines 1994; Deutsch et al. 1993; Coverman 1985).

Lastly, the gender relations perspective presents socialisation processes as an adaptation to the different socially constructed roles, expressed, for example, in the sexual division of work. Thus, gender is a behaviour conditioned by the social expectations and norms some people have of the behaviour of others (Killewald and Gough 2010; Gupta and Ash 2008; Davis et al. 2007; Gupta 2007; Fuwa 2004; Brines 1994). In this regard, several studies observe a positive relation between the egalitarian gender attitudes and roles of the couple and a fairer division of the domestic and care work (Kan and Gershuny 2010; Sevilla-Sanz et al. 2010; Treas and Drobnic 2010; Knudsen and Wearness 2008; Davis et al. 2007; Fuwa 2004; Parkman 2004; Greenstein 1996).

The main hypotheses of the empirical study related to the factors explaining the gender gap in domestic and care work, on a microsocial level, are:

Hypothesis 1. Women's relative resources will have a greater effect on the gap than those of men: reducing in those women with high relative resources (occupation, education and economic resources).

Hypothesis 2. The models and effect magnitudes of the variables explaining the gender gap will be different for women and men, indicating the relevance of the gender roles.

Hypothesis 3. The gender gap will be wider in those households with greater care needs; especially with the presence of children and dependent peoples.

On a macrosocial level, and from a comparative analysis of the countries analysed, hypothesis 4 is that in those countries with less egalitarian gender values and where attitudes promoting the allocation of work according to gender relations persist, a wider gender gap will be observed.

The empirical analysis is conducted on the basis of surveys for each country which gather information about the use of time dedicated to work in the labour market, unpaid work and personal activities of the population (spanning over 12 years in Chile, over 18 years in Argentina; 10 years in Spain and 14 in Uruguay). Specifically, the analysis will examine data from the Time-use Survey which collected data through the application of a daily diary (INE, Spain 2011); those of the Module of Unpaid Work and Time Uses from the Annual Urban Household Survey (INDEC, Argentina 2013) ${ }^{5}$; those of the Time-use Surveys of Chile and Uruguay (INE, Chile 2016; INE, Uruguay 2013). In these last three cases, the survey is based

\footnotetext{
${ }^{5}$ The Argentinian survey is the only one that is a module added to a regular survey, where questions about paid work are included. In addition, it also includes a list of activities of limited unpaid work. A first block is dedicated to unpaid domestic and care work, including domestic chores; looking after children, sick people or adults in the home; and activities dedicated to school and/or learning support for members of the household.
} 
on a list of activities predefined in the Classification of Time-use Activities for Latin America and the Caribbean (CAUTAL), which uses the International Classification of Activities for Time Use Statistics (ICATUS) as a reference, which was used in the Spanish survey.

Since two different tools are used to collect information - a time-use diary and a list of activities-(Carrasco and Domínguez 2014) and to increase the comparability of the surveys, the analysis focuses on the gender gap in the distribution of domestic and care work between both components of the couple: the chief female and male person. Thus, the dependent variable is the contribution of each member of the couple to the total domestic and care time dedicated in the home, on a typical day, for the two main people: calculating first the total time both people dedicate to the household, and then the proportion carried out by each member.

Lastly, it is important to point out that the analyses are conducted for dual-income heterosexual couples since it is considered that it is these couples in which both members have resources for intra-family negotiation and are more egalitarian in terms of gender mandates regarding women and the labour market (Ajenjo and García 2011; Daly 2011; Gálvez et al. 2010; Kan et al. 2011; Sayer 2010; González and Jurado 2009). The final sample, made up of households of dual-income couples, is 5730 households in Argentina, 1671 in Chile, 1771 in Spain and 966 in Uruguay.

As regards the data analysis techniques, a linear regression model is formulated for each country, in which the independent variables implement the different micro theories presented above: (i) those variables that provide information about the relative resources of women and men: age, education level, socio-professional category and personal income; (ii) the time dedicated by women and men to paid work, and the total time dedicated by the couple to domestic and care work; (iii) characteristics of the household and care needs (type of household according to the presence and age of minors, number of minors and domestic service). In the regression models, one per country, both quantitative and qualitative variables, transformed into dummy variables, are used.

\subsection{Analysis Results}

The first general results (Table 11.5) show, for all the countries, a greater overall workload for women, with Argentina being the most unequal country in the relation between men and women. Specifically, for unpaid domestic and care work, in Spain the ratio between men and women is lower, followed by Chile, Uruguay and, lastly, Argentina where the time gap is wider. This highlights the considerable feminisation of unpaid work, and, on the contrary, women's lower participation in paid work in the four countries, with the differences in Argentina being more critical in descriptive terms ${ }^{6}$.

As regards the empirical evidence that is most relevant to this work, first (see Table 11.6), the results about the explanatory capacity of the models show that the

${ }^{6}$ This result may be due to the Argentinian survey not collecting information about time if dedication did not reach a minimum of $1 \mathrm{~h}$ daily. This under-recorded the declaration of care work by men. 


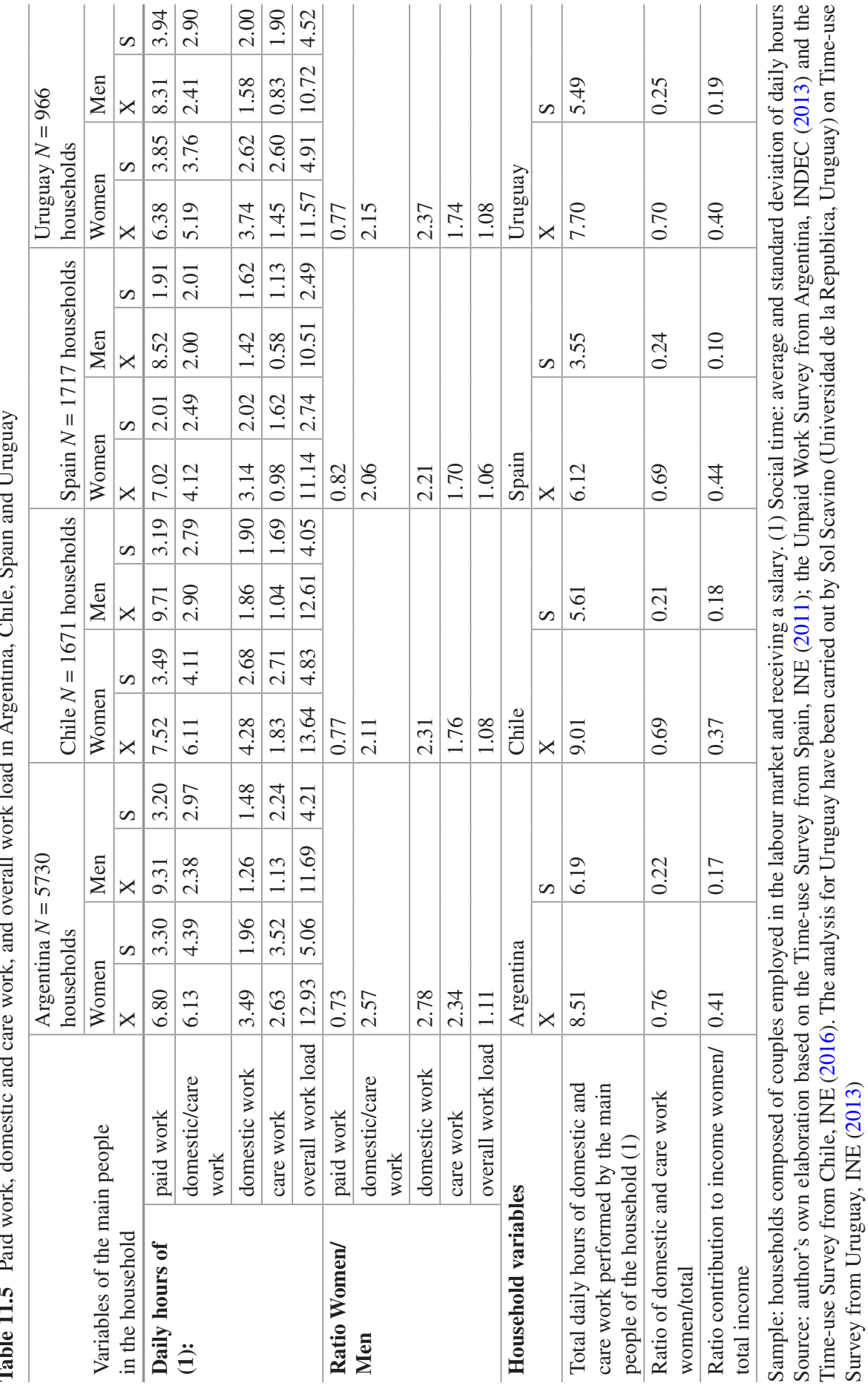




\begin{tabular}{|c|c|c|c|c|c|c|c|c|c|c|c|c|c|c|}
\hline 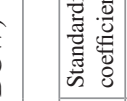 & $\begin{array}{l}\frac{\pi}{0} \\
\infty\end{array}$ & & $\begin{array}{l}\text { 总 } \\
\text { o. } \\
\text { i }\end{array}$ & $\frac{\text { }}{i}$ & 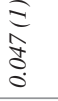 & E. & $\stackrel{\infty}{\infty}$ & క. & $\begin{array}{l}5 \\
\text { \$ } \\
i\end{array}$ & 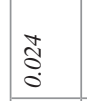 & §ै & $\begin{array}{l}\stackrel{\circ}{0} \\
\delta \\
0\end{array}$ & $\begin{array}{l}\text { ô } \\
0 \\
i\end{array}$ & $\begin{array}{l}\infty \\
\widetilde{\Xi} \\
i \\
i\end{array}$ \\
\hline \multirow{3}{*}{ 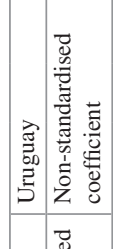 } & 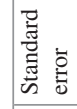 & م. & $\exists$ & $\stackrel{\infty}{?} \stackrel{0}{0}$ & & $\underset{t}{t}$ & f & 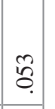 & & & & & & \\
\hline & & $*$ & * & $\begin{array}{l}* \\
* \\
*\end{array}$ & & * & * & 蜜 & & & & & & \\
\hline & $\infty$ & \begin{tabular}{l}
$\mathscr{\infty}$ \\
$\infty$ \\
\hdashline \\
$\sigma$
\end{tabular} & $\begin{array}{c}\text { Cִ } \\
\text { I. }\end{array}$ & \begin{tabular}{|c|}
0 \\
0 \\
0 \\
$i$ \\
1
\end{tabular} & a & $\begin{array}{l}0 \\
i \\
i \\
1\end{array}$ & 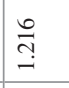 & $\stackrel{\text { I }}{\leftrightharpoons}$ & (a) & $\widehat{d}$ & $\widehat{d}$ & $\widehat{d}$ & $\widehat{d}$ & $\widehat{d}$ \\
\hline 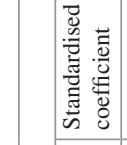 & 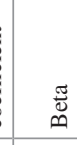 & & $\begin{array}{l}0 \\
0 \\
i \\
i\end{array}$ & 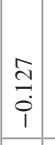 & $\begin{array}{l}\bar{\Sigma} \\
\text { ָे } \\
\text { i } \\
i\end{array}$ & $\begin{array}{l}m \\
0 \\
i\end{array}$ & $\stackrel{0}{0}$ & $\begin{array}{l}0 \\
\vdots \\
\vdots \\
0 \\
0 \\
0\end{array}$ & $\begin{array}{l}0 \\
\frac{2}{0} \\
0\end{array}$ & $\begin{array}{l}\overline{\bar{z}} \\
\overline{0} \\
0 \\
i \\
\end{array}$ & $\begin{array}{l}\bar{z} \\
\vdots \\
0 \\
0 \\
i\end{array}$ & $\overrightarrow{\vec{o}}$ & $\Xi$ & $\begin{array}{l}\text { to } \\
\text { i } \\
\end{array}$ \\
\hline \multirow{3}{*}{ 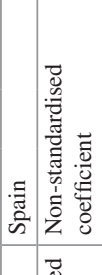 } & 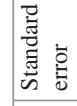 & $\underset{\substack{\infty \\
\infty}}{\tilde{\infty}}$ & $\frac{\pi}{0}$ & స్తి & & $\frac{m}{\pi}$ & तี & & 它. & & & 守 & 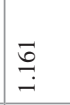 & $\begin{array}{l}0 \\
\vdots \\
0 \\
0\end{array}$ \\
\hline & & 宩 & $\begin{array}{l}* \\
* \\
*\end{array}$ & 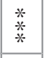 & & 苂 & 菜 & & 䊉 & & & 丵 & 桻 & * \\
\hline & $\infty$ & $\begin{array}{l}\underset{J}{J} \\
\infty \\
\infty\end{array}$ & 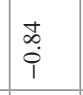 & $\begin{array}{c}0 \\
0 \\
0 \\
0 \\
1\end{array}$ & a & $\begin{array}{l}n \\
\text { an } \\
\\
1\end{array}$ & $\begin{array}{l}\hat{\partial} \\
\text { ì }\end{array}$ & $\widehat{d}$ & $\begin{array}{l}f \\
f \\
0 \\
0\end{array}$ & $\widehat{d}$ & $\widehat{d}$ & $\begin{array}{l}\begin{array}{c} \pm \\
\infty \\
n \\
n \\
n\end{array} \\
n\end{array}$ & ते & 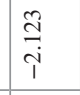 \\
\hline 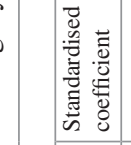 & 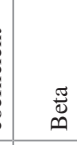 & & $\begin{array}{l}\tilde{n} \\
0 \\
i \\
i\end{array}$ & $\begin{array}{l}0 \\
\vdots \\
0 \\
i \\
i\end{array}$ & 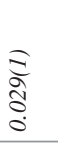 & $\begin{array}{l}\infty \\
0 \\
0 \\
i \\
1\end{array}$ & $\frac{t}{0}$ & $\frac{0}{3}$ & $\begin{array}{c}0 \\
0 \\
0 \\
0 \\
0 \\
1\end{array}$ & 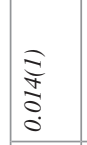 & $\begin{array}{l}\bar{\Xi} \\
\vdots \\
\vdots \\
0 \\
i\end{array}$ & o̊ & $\frac{\pi}{0}$ & $\begin{array}{l}\overline{\overline{0}} \\
\stackrel{0}{0} \\
i \\
i\end{array}$ \\
\hline \multirow{3}{*}{ 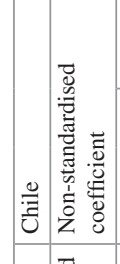 } & 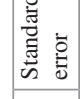 & 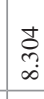 & 苜 & 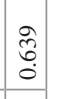 & & $\frac{5}{0}$ & $\frac{a}{5}$ & 足 & & & & bे & $\stackrel{\infty}{\stackrel{\infty}{\leftrightarrows}}$ & \\
\hline & & * & * & 善 & & 养 & 丵 & $*$ & & & & 粘 & * & \\
\hline & $\infty$ & $\begin{array}{l}\stackrel{2}{c} \\
\hat{i} \\
i\end{array}$ & $\begin{array}{l}\text { Oे } \\
\text { ì } \\
i\end{array}$ & $\mid \begin{array}{c}\infty \\
\stackrel{\infty}{0} \\
i \\
\end{array}$ & త & $\begin{array}{l}0 \\
\infty \\
n \\
i \\
1 \\
1\end{array}$ & 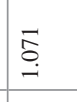 & \begin{tabular}{|c|} 
\\
ç \\
con
\end{tabular} & $\widehat{a}$ & $\widehat{d}$ & $\widehat{d}$ & 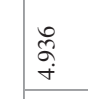 & $\frac{\hat{m}}{\dot{m}}$ & $\widehat{d}$ \\
\hline 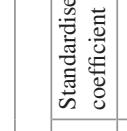 & 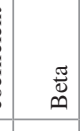 & & 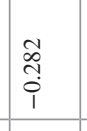 & $\mid \begin{array}{l}0 \\
o \\
0 \\
1\end{array}$ & $\begin{array}{l}\overline{0} \\
\text { gे } \\
0\end{array}$ & $\begin{array}{l}0 \\
\stackrel{0}{0} \\
0 \\
1\end{array}$ & $\stackrel{0}{\stackrel{0}{0}}$ & $\mid \begin{array}{l}0 \\
0 \\
0 \\
0\end{array}$ & $\begin{array}{l}\vec{o} \\
. \\
\end{array}$ & 总 & 勇 & ه̊: & 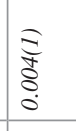 & $\begin{array}{l}\bar{z} \\
\overline{8} \\
0 \\
i \\
1\end{array}$ \\
\hline \multirow{4}{*}{ 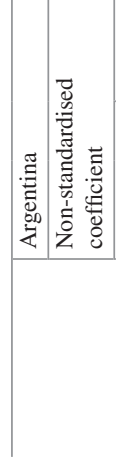 } & 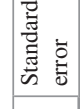 & g) & ठ̀. & 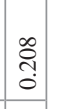 & & 总 & do & $\begin{array}{l} \pm \\
\stackrel{5}{0}\end{array}$ & $\begin{array}{l}\infty \\
\text { तj } \\
0\end{array}$ & $\begin{array}{l}\text { कo } \\
\text { of } \\
0\end{array}$ & $\begin{array}{l}\vec{f} \\
0 \\
0\end{array}$ & \begin{tabular}{|l}
$\hat{0}$ \\
$\tilde{c}$ \\
0 \\
0
\end{tabular} & & \\
\hline & & * & $\stackrel{*}{*}$ & $\begin{array}{l}* \\
* \\
*\end{array}$ & & 䊉 & 夈 & $*$ & 荬 & \begin{tabular}{|l} 
竝 \\
\end{tabular} & 糗 & $\begin{array}{l}* * * \\
*\end{array}$ & & \\
\hline & 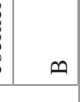 & 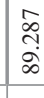 & $\frac{\hat{8}}{i}$ & \begin{tabular}{|c}
5 \\
5 \\
$\mathfrak{y}$ \\
$i$ \\
\end{tabular} & d & \begin{tabular}{|l} 
\pm \\
0 \\
0 \\
$i$
\end{tabular} & $\begin{array}{l}F \\
\text { g } \\
\text {. }\end{array}$ & 敨 & בְ & $\begin{array}{l}0 \\
\tilde{y} \\
\text { in } \\
\text {. }\end{array}$ & 导 & 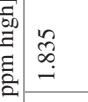 & $\widehat{d}$ & $\widehat{d}$ \\
\hline & & 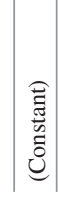 & 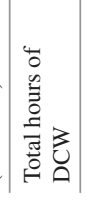 & 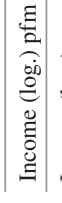 & 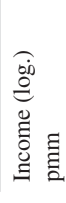 & 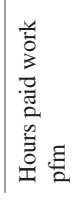 & 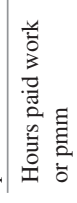 & 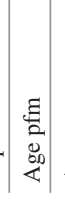 & & 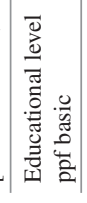 & 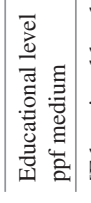 & 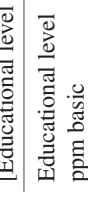 & 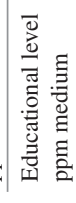 & 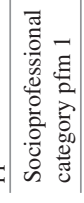 \\
\hline
\end{tabular}




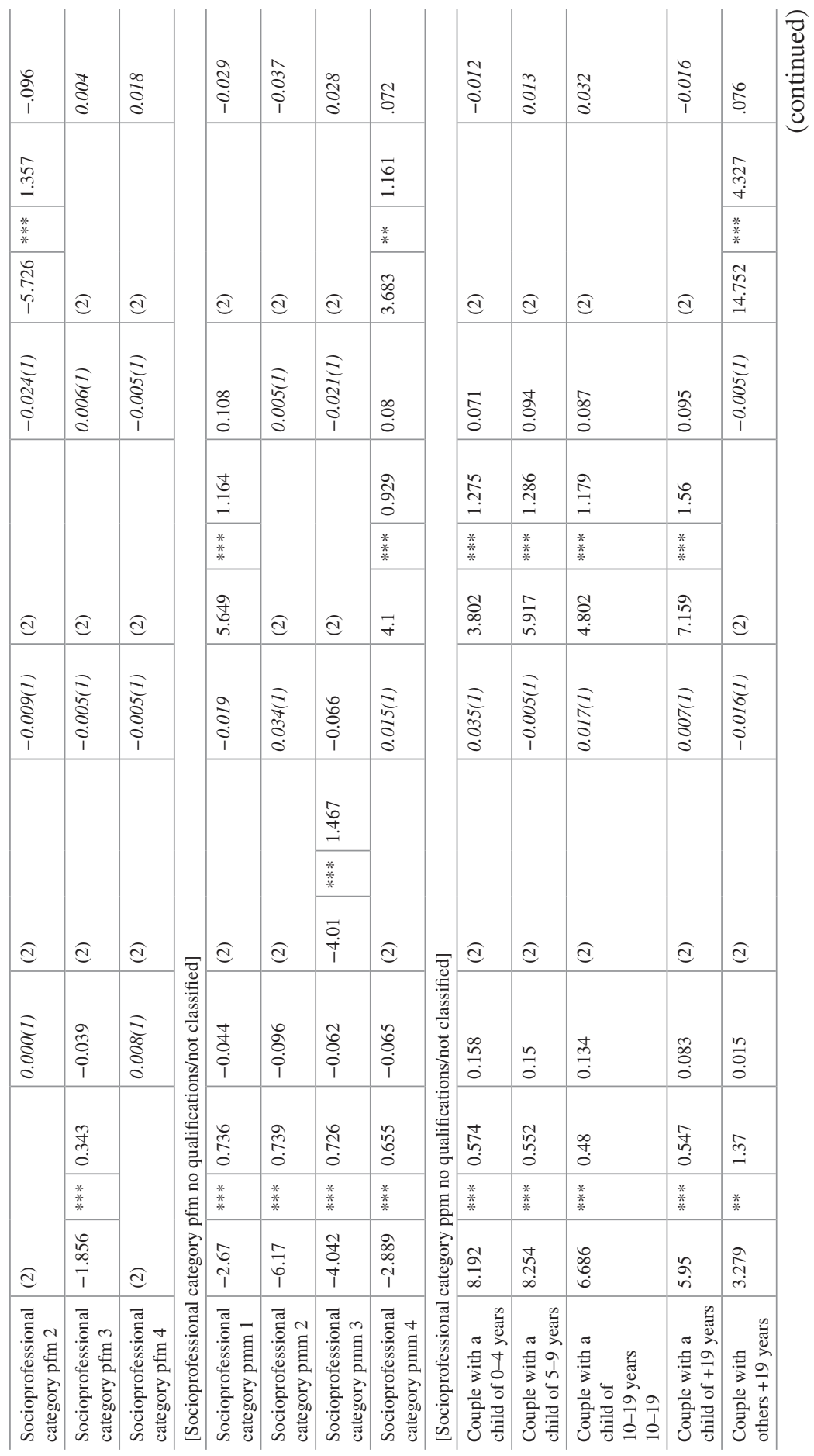




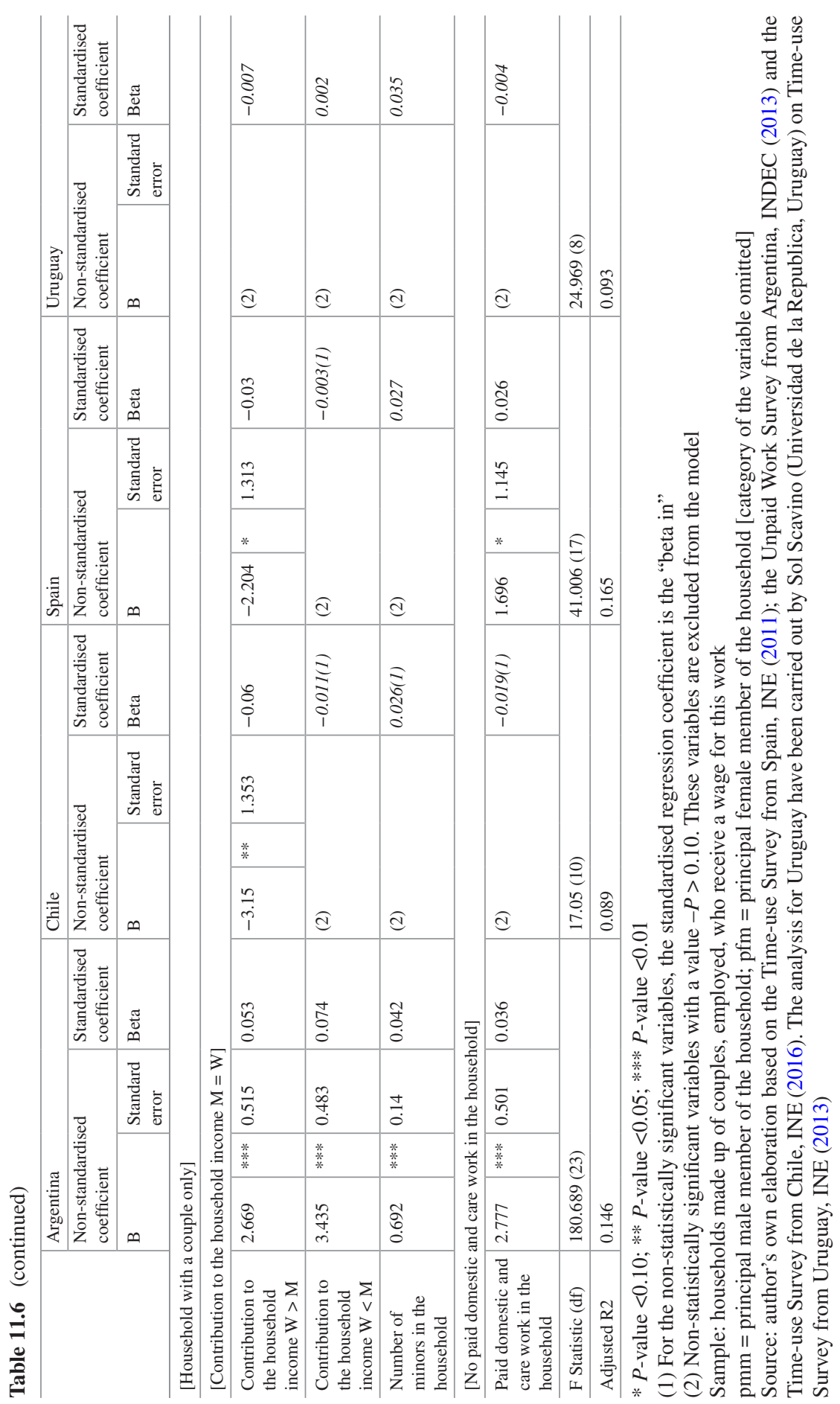


relative resources of men and women and their impact on the negotiation capacity within the household have a limited effect on understanding the gender gap in the distribution of time-use in unpaid work.

Moreover, if the differences between countries are analysed, the hierarchy and magnitude of the most relevant factors explaining the gap between men and women, is notable. Thus, in Argentina, the total hours of domestic and care work performed by the main people in the household have a greater impact on the gender gap: the more hours of total dedication, the more the inequality in the distribution reduces. On the contrary, in Chile, Uruguay and Spain, men's dedication to paid work is the variable which best explains the gender gap: the availability of male time is an important factor for understanding the phenomenon.

These first results show the relevance of the interrelation between the work times (paid and unpaid) to understand the gender gap in domestic and care work; affecting women and men differently. Both in the case of women and men, increasing their hours of dedication to paid work means reducing the time dedicated to domestic and care work. However, in terms of inequality, this occurs in a different way since the effect of the increase in men's dedication to paid work on the gender gap in unpaid work has an amplifying effect on inequality that is much greater than the reducing effect observed when the woman increases her dedication to the labour market.

Furthermore, women's economic income has been one of the factors most examined in the literature, with some contradictory results being highlighted in several studies. In the empirical work conducted, the results are evident: the higher women's salary income, the lower the inequality. On the contrary, if the analysis focuses on women's economic contribution to the economic income of the household, a greater contribution from women has a significant effect in Spain and especially in Chile: reducing the gender gap in unpaid work. However, in Argentina, households that are more egalitarian in the distribution of domestic and care work are those where there is greater salary equality. Contrary to that set out by the theoretical perspective of relative resources, this situation may reveal the lower negotiation capacity of Argentinian women and the strength and influence of gender norms and values on the distribution of work in the households. In less egalitarian contexts in terms of gender ideologies, those women who transgress them through their earning capacity in the labour market strengthen their female gender role in the household, and, therefore, assume more unpaid work, as a way of compensating for their transgression of social and cultural gender values.

The analysis of the effects of educational levels and the socio-professional categories of women and men on the gender gap in domestic and care work shows highly diverse and variable results between countries, confirming that indicated by previous studies (Knudsen and Wearness 2008; Fuwa 2004).

Thus, as regards education levels, if the emphasis is placed on women, it can be observed that it is only in Argentina where a higher educational level means a reduction in inequality. On the contrary, in the other countries, the dominant effect is men's education level: their low education levels intensify the inequalities between women and men.

A similar approach provides us with the results from the socio-professional categories: a greater explanatory capacity of the situation of men, especially in 
Argentina, where men from all socio-professional categories, compared to unskilled men, show a lower inequality in the distribution; especially in the categories of midlevel technicians, office employees and employees in the services and commerce industries. This last category (service and commerce employees) is the only category that has a reducing effect on inequality in Chile. In turn, in Spain, the categories of managers and high-level technicians and skilled workers show a significant effect on an increase in inequality.

In the case of women, the socio-professional category shows more unstable and inconsistent results: with no significant effect in Chile; lower inequality in higher categories in Spain and Argentina (legislative and judicial power; manager and technician, professional and scientific); and in female mid-level technicians and administrative and office employees in Uruguay.

Lastly, as regards the household variables, the presence of minors in the household is one of the most critical situations entailing an increase in the care needs in the household and the establishment of family strategies to meet these needs, particularly when the children are aged below 9 years of age. The results observed, taking as a reference households of couples without other people, show that Chile and Uruguay have a totally different pattern: the presence of minors in the household, regardless of the age, increases the hours dedicated to care work but it does not have a significant effect on the distribution gap of domestic and care work of men and women, without modifying the inequality pattern in dedication. In turn, the Argentinian and Spanish cases reveal much more unequal situations: with the presence of minors aged less than 4 and up to 9 , the increase in the dedication time means that women assume a greater load of this work, and consequently gender inequalities increase.

In this regard, it is important to point out that the maintenance of inequality in the household between the two main people, female and male, depending on the presence of minors, may be due to the role of people outside of the household; especially of grandmothers and grandfathers or external services, when the households can afford it.

Regarding this last point, when part of the domestic and care work is performed by another person (mainly a woman) as a paid job, part of the work performed by men is reduced, but not the work assumed by women. Women probably reduce part of the domestic and care work, the most routine and easily outsourced, but they manage, organise and "are alert" to tasks and care. Therefore, paid domestic work either has no effect on the gender gap in Chile and Uruguay, or it increases the inequality between men and women (Argentina 1.7 and Spain 2.7).

\subsection{Conclusions}

At the beginning of the chapter we highlighted the need to broaden the operational definition of the theoretical constructs of work and times, incorporating measures that embrace the multi-dimensional nature of these concepts and the dualities affecting them. This broadening would help, first, to incorporate gender relations and 
values, into the analysis of gender gaps in productive and reproductive time-use. Second, it would also mean relevant progress in the recognition of inequality processes, highlighting the suitability of opening up the analysis towards the great absentee of care work, the male gender, and the permanence of other axes of inequality and social stratification in care time.

The analyses conducted help to observe, on a comparative level in Europe and Latin America, that, although a reduction has been detected in gender differences in time-use over the past 50 years, as a result of more women dedicating increased time to paid work and more men dedicating increased time to domestic and care work, the gender segregation in relation to domestic work persists.

The models considered in the four countries analysed to give an account of the gender gap in domestic and care work show the low incidence of those variables which have been considered in the contributions of "relative resources": women's education levels, socio-professional categories and economic resources. These results are consistent with that indicated in other comparative studies regarding the weakness and inconsistency of relative resources in the negotiation capacity in the distribution of time dedicated to unpaid care work. Moreover, said relative resources have different magnitudes and effects according to whether they are men's or women's.

In the case of women, their participation in paid work and their economic income are relevant factors for reducing the inequality gap. Therefore, it is unquestionable that the elimination of economic inequalities is a relevant element in overcoming the gender gap in unpaid work.

This result serves to verify the association between the socioeconomic stratification of women and gender relations.

On the contrary, men's relative resources, their education level and socioprofessional category, are more consistent and of a larger magnitude, especially in Latin American countries. This may reflect the greater diversity of male gender ideologies and values, and a greater effect of male socio-economic stratification on the gender gap: their relative positions have a greater impact on their dedication to domestic and care work, and consequently on the distribution of time in the household.

Therefore, the inequalities in the social relations of production intersect with the maintenance of relations of gender inequality. Consequently, women from popular classes and more disadvantaged households assume greater inequality in unpaid work in households.

This weakness of relative resources, as a negotiation capacity, in the understanding of the processes underlying gender gaps, is accompanied by the relevance of the gender ideologies, roles and attitudes underlying the sexual division of work and the gender gap in the carrying out of domestic and care work. In the Latin American countries, androcentric cultural and social norms and values persist to a greater extent, and men and women continue to be assigned to jobs according to gender relations. In this regard, the results all reveal the need to incorporate the gender ideology and contextual elements in the explanation of the gender gap in households. In other words, accompanying the time-use surveys with qualitative studies 
or with questions, included in the surveys, which serve to gather information about the social representations of gender and care.

Likewise, the importance of the interrelation between times is notable. In all the countries, the greater dedication of men to work in the labour market does not only mean a reduction in their domestic and care work, but, as a consequence, women either have to reduce their dedication to the labour market to assume the reduction in men's work in the household, or outsource part of it. Therefore, the availability of time and its effect on the gender gap in the domestic and care work load, and the overall work load, fit in with the male strategy, but not the female, which responds more to the care needs of the household.

To conclude, the empirical results reaffirm that women dedicate time to domestic and care work in accordance with the care and welfare needs of the people in the household. The gender gap is sensitive to this and shows that female time is the adjustment variable, with consequences on the quality of life and welfare of women. And male time is the key factor to achieve equity in work times.

\section{References}

Adam, B. (2004). Time. Cambridge: Polity Press.

Almeda, E., et al. (2016). Familias monoparentales, inclusión y comunidad. Arxius de Ciencies Socials, 34, 59-78.

Aguirre, R. (2015). Avances en la medición del uso del tiempo y el trabajo no remunerado en la región. In K. Batthyány (Ed.), Los tiempos del bienestar social. Instituto Nacional de las Mujeres. Ministerio de Desarrollo Social: Montevideo.

Aguirre, R. (2003). Género, ciudadanía social y trabajo. Montevideo: Doble Clic Editoras.

Aguirre, R., \& Ferrari, F. (2014). Las encuestas sobre el uso del tiempo y trabajo no remunerado en América Latina y El Caribe. Caminos recorridos y desafíos hacia el futuro. Serie asuntos de género, 122. Santiago de Chile: CEPAL.

Ajenjo, M., \& García, J. (2011). El tiempo productivo, reproductivo y de ocio en las parejas de doble ingreso. Papers, 96(3), 985-1006.

Amarante, V., \& Rossel, C. (2017). Unfolding patterns of unpaid household work in Latin America. Feminist Economics, 24(1), 1-34.

Antonopoulos, R. (2008). The unpaid care work-paid work connection. Levy Economics Institute: Working Papers Series.

Antonopoulos, R., \& Hirway, I. (Eds.). (2010). Unpaid work and the economy gender, time use and poverty in developing countries. Londres: Palgrave Macmillan.

Aulenbacher, B., et al. (2018). Capitalism goes care: elder and child care between market, state, profession, and family and questions of justice and inequality. Equality, Diversity and Inclusion: An International Journal, 37(4), 347-360.

Arriagada, I. (2007). Familias y políticas públicas en América Latina: una historia de desencuentros. Santiago de Chile: CEPAL.

Bárcena, A. (2011). Spreading the wealth. Finance \& Development, 48(1).

Batthyány, K., \& Scavino, S. (2017). División sexual del trabajo en Uruguay en 2007 y 2013. Tendencias en los cambios y en las permanencias de las desigualdades de género. Revista Austral de Ciencias Sociales, 32, 121-114.

Batthyány, K. (Ed.). (2015a). Los tiempos del bienestar social. Instituto Nacional de las Mujeres. Montevideo: Ministerio de Desarrollo Social. 
Batthyány, K. (2015b). Las políticas y el cuidado en América Latina: una mirada a las experiencias regionales. Santiago de Chile: CEPAL.

Bernhardt, E., Noack, T., \& Lyngstad, T. H. (2008). Shared housework in Norway and Sweden: Advancing the gender revolution. Journal of European Social Policy, 18, 275-288.

Bettio, F., Corsi, M., D'Ippoliti, C., Lyberaki, A., Samek, M., \& Verashchagina, A. (2012). The impact of the economic crisis on the situation of women and men and on gender equality policies. Luxemburg: European Union.

Bianchi, S. et al. (2000). Is anyone doing the housework? Trends in the gender division of household labor. Social Forces, 79, 191-228.

Blofield, M., \& Martínez, J. (2014). Trabajo, familia y cambios en las políticas públicas en América Latina: equidad. maternalismo y corresponsabilidad. Revista de la CEPAL, 114, 107-125.

Brines, J. (1994). Economic Dependency, Gender, and the Division of Labor at Home. American Journal of Sociology, 100(3), 652-688.

Bundlender, D. (2010). What do time use studies tell us about unpaid care work? Evidence from seven countries a time use studies and unpaid care work. New York: Routledge.

Calero, A., Dellavalle, R., \& Zanino, C. (2015). Uso del tiempo y economía del cuidado. Work document, Nr. 09. Secretaría de política económica y planificación del desarrollo. Buenos Aires: Subsecretaría Programación Económica.

Campaña, J. C., Giménez-Nadal, J., \& Alberto Molina, J. (2017). Gender norms and the gendered distribution of total work in Latin American households. Feminist Economics, 24(1), 35-62.

Carrasco, C. (2016). El tiempo más allá del reloj: las encuestas de uso del tiempo revisitadas. Cuadernos de relaciones laborales, 34(2), 357-386.

Carrasco, C. (2013). El cuidado como eje vertebrador de una nueva economía. Cuadernos de relaciones laborales, 31(1), 39-56.

Carrasco, C. (2005) Tiempo de trabajo, tiempo de vida. Las desigualdades de género en el uso del tiempo. In Aguirre, R., García, C., Carrasco, C. (Eds.), El tiempo, los tiempos, una vara de desigualdad. Santiago de Chile: Naciones Unidas, CEPAL, Unidad Mujer y Desarrollo, Nr. 65 , July.

Carrasco, C., \& Domínguez, M. (2011). Family strategies for meeting care and domestic work needs: Evidence from Spain. Feminist Economics, 17(4), 159-188.

Carrasco, C., \& Domínguez, M. (2014). Measured time, perceived time: A gender bias. Time and Society, 24(3), 326-347.

Carrasco, C., \& Recio, A. (2014). Del tiempo medido a los tiempos vividos. Revista de Economía Crítica, 17, 82-97.

Carrasquer, P. (2013). El redescubrimiento del trabajo de cuidados: algunas reflexiones desde la sociología. Cuadernos de Relaciones Laborales, 31(1), 91-113.

Castelló, L. (2011). Trabajo de cuidado, género y clase social. emedios desiguales a un problema común. RSociología del Trabajo, 73, 24-41.

CEPAL. (2016). La matriz de la desigualdad social en América Latina. Santiago de Chile.

CEPAL. (2017a). Repositorio de información sobre uso del tiempo de América Latina y el Caribe. Santiago de Chile.

CEPAL. (2017b). Estrategia de Montevideo para la Implementación de la Agenda Regional de Género en el marco del Desarrollo Sostenible hacia 2030. Santiago de Chile.

Coverman, S. (1985). Explaining husbands' participation in domestic labor. Sociological Quarterly, 26(1), 81-97.

Daly, M. (2011). What adult worker model? A critical look at recent social policy reform in Europe from a gender and family perspective. Social Politics: International Studies in Gender. State \& Society, 18(1), 1-23.

Davis, S., Greenstein, T., \& Gerteisen, M. (2007). Effects of union type on division of household labor: Do cohabiting men really perform more housework? Journal of Family Issues, 28(9), $1246-1272$.

Deutsch, F., Lussier, J., \& Servis, L. (1993). Husbands at home: Predictors of paternal participation in childcare and housework. Journal of Personality and Social Psychology, 65(6), 1154-1166. 
Domínguez, M. (2020). Lecciones aprendidas en la medición de los tiempos de cuidados. Clacso: Miradas Latinoamericanas al cuidado. In Press.

Domínguez, M., Muñiz, L., \& Rubilar, G. (2019). El trabajo doméstico y de cuidados en las parejas de doble ingreso. Análisis comparativo entre España, Argentina y Chile. Papers, Revista de Sociología, 104(2).

Durán, M. A. (1997). La investigación sobre uso del tiempo en España: algunas reflexiones metodológicas, en Revista Internacional de Sociología, 18, septiembre-diciembre, 163-189.

Durán, M. A., \& Milosavijevic, V. (2012). Unpaid work, time use surveys and care demand. Fundación BBVA: Forecasting in Latin America. Bilbao.

Espejo, A., Filgueira, F., \& Rico, A. (2010). Familias latinoamericanas: organización del trabajo no remunerado y de cuidado. Santiago de Chile: CEPAL.

EUROSTAT. (2008). Harmonised European time use surveys. Comisión Europea: Guidelines. Methodologies and Working Papers. Luxemburgo.

Eurostat (2010). Eurostat, (2018 April 14) Time Use Survey [Data file]. Retrieved from https:// appsso.eurostat.ec.europa.eu/

Ferrant, G., Pesando, L., \& Nowacka, K. (2014). Unpaid care work: The missing link in the analysis of gender gaps in labour outcome. Geneva: OECD.

Folbre, N. (2008). Valuing children rethinking the economics of the family. Cambridge, Mass: Harvard University Press.

Fraser, N. (2016). Contradictions of Capital and Care. New Left Review, 100, 99-117.

Fuwa, M. (2004). Macro-level gender inequality and the division of household labor in 22 countries. American Sociological Review, 69, 751-767.

Gálvez, L., \& Rodríguez-Madroño, P. (2011). La desigualdad de género en las crisis económicas. Investigaciones Feministas, 3, 113-132.

Gálvez, L., Rodríguez-Modroño, P., \& Domínguez-Serrano, M. (2010). Género, trabajos y usos del tiempo en España dentro del contexto europeo. In A. Villar (Ed.), Mujeres y mercado laboral en España: cuatro estudios sobre la discriminación salarial y la segregación laboral. FBBVA: Bilbao.

Geist, C. (2005). The welfare state and the home: Regime differences in the domestic division of labour. European Sociological Review, 21(1), 23-41.

Gershuny, J., \& Sullivan, O. (2003). Time use, gender, and public policy regimes. Social Politics: International Studies in Gender. State \& Society, 10, 205-228.

Gershuny, J. (2000). Changing. In Times: Work and leisure in postindustrial. Society. Oxford: Oxford University Press.

Goñalons-Pons, P. (2015). Gender and class housework inequalities in the era of outsourcing hiring domestic work in Spain. Social Science Research, 52, 208-218.

González, M. J., \& Jurado, T. (2009). Cuándo se implican los hombres en las tareas domésticas? Un análisis de la encuesta de empleo del tiempo. Panorama Social, 10, 65-81.

Greenstein, T. (1996). Gender Ideology and Perceptions of the Fairness of the Division of Household Labor: Effects on Marital Quality. Social Forces, 74(3), 1029-1042.

Gupta, S., \& Ash, M. (2008). Whose money. whose time? A nonparametric approach to modeling time spent on housework in the United States. Feminist Economics, 14(1), 93-120.

Gupta, S. (2007). Autonomy, Dependence, or Display? The Relationship Between Married Women's Earnings and Housework. Journal of Marriage and Family, 69(2), 399-417.

Harmonised European Time Use Survey statistics (HETUS). (n.d.) Accessed on November, 2019.

Hochschild, A. (2002). Las cadenas mundiales de afecto y asistencia y la plusvalía emocional. In W. Hutton \& A. Giddens (Eds.), En el límite: La vida en el capitalismo global (pp. 187-208). Barcelona: Tusquets Editores.

Hook, J. (2006). Care in context: Men's unpaid work in 20 countries, 1965-2003. American Sociological Review, 71, 639-660.

INE-Chile instituto nacional de estadísticas. (2016). ENUT Encuesta Nacional Sobre Uso del Tiempo. INE: Documento Metodológico. Santiago de Chile.

Inglehart, R., Haerpfer, C., Moreno, A., Welzel, C., Kizilova, K., Diez-Medrano, J., Lagos, M., Norris, P., Ponarin, E., \& Puranen, B. (Eds.). (2014). World values survey: round six-countrypooled datafile. Madrid: JD Systems Institute. 
Instituto nacional de estadística del Uruguay. (2013). Uso del tiempo y trabajo no remunerado en Uruguay. Montevideo: INE.

Instituto nacional de estadística español (INE) (2011). Encuesta de Empleo del Tiempo 2009-2010. Metodología. Madrid: INE.

Instituto nacional de estadística y censos (INDEC). (2013). Encuesta sobre Trabajo no Remunerado y Uso del Tiempo Informe técnico. INDEC: Diseño de registro y estructura de la base de microdatos. Buenos Aires.

Izquierdo, M. J. (1998). El malestar en la desigualdad. Madrid: Cátedra.

Jiménez-Martín, S., \& Vilaplana, C. (2012). Trade-off between formal and informal care in Spain. European Journal of Health Economics, 13(4), 461-490.

Kan, M., \& Gershuny, J. (2010). Gender segregation and bargaining in domestic labour. In R. Cromptom, J. Scott, \& C. Lyonnett (Eds.), Evidence from longitudinal time use data. In Gender inequalities in the 21st Century. Aldershot: Edward Elgar.

Kan, M., Sullivan, O., \& Gershuny, J. (2011). Gender convergence in domestic work: discerning the efects of interactional and institutional barriers from large-scale data. Sociology, 45(2), 234-251.

Karamessini, M., \& Rubery, J. (2014). Women and austerity: The economic crisis and the future for gender equality. New York: Routledge.

Killewald, A., \& Gough, M. (2010). Money isn't everything: wives' earnings and housework time. Social Science Research., 39(6), 987-1003.

Knudsen, K., \& Wearness, K. (2008). National context and spouses' housework in 34 countries. European Sociological Review, 24(1), 97-113.

Kofman, E., \& Raghuram, P. (2015). Gendered Migrations and Global Social Reproduction. Houndmills, Basingstoke, Hampshire: Palgrave Macmillan.

Lachance-Grzela, M., \& Bouchard, G. (2010). Why do women do the lion's share of housework? A decade of research. Sex Roles, 63, 767-780.

Lewis, J. (2010). Gender and welfare state change. European Societies, 4(4), 331-357.

Lewis, J. D., \& Weigert, A. (1992). Estructura y significado del tiempo social. In R. Ramos (Ed.), Tiempo y sociedad (pp. 89-131). Madrid: CIS.

López Gil, S., \& Pérez Orozco, A. (2011). El análisis de las cadenas: ¿Reproducción de un régimen de cuidados injusto? En Desigualdades a flor de piel: cadenas globales de cuidados: Concreciones en el empleo de hogar y políticas públicas. Madrid: ONU Mujeres.

Lutz, H. (2017). Care as a fictitious commodity: Reflections on the intersections of migration, gender and care regimes. Migration Studies, 5(3), 356-368.

Mannino, C., \& Deutsch, F. (2007). Changing the division of household labor: A negotiated process between partners. Sex Roles, 56(5-6), 309-324.

Marini, M., \& Shelton, B. (1993). Measuring household work: Recent experience in the United States. Social Science Research, 22, 361-382.

Martínez-Buján, R. (2014). Los modelos territoriales de organización social del cuidado a personas mayores en los hogares. Revista Española de Investigaciones Sociológicas, 145, 99-124.

Martinez, J., \& Voorend, K. (2013). Desigualdades de género en los regímenes de bienestar latinoamericanos: Mercado, política social y organización familiar de los cuidados. In L. Pautassi \& C. Ziebecchi (Eds.), Las fronteras del cuidado: Agenda, derechos e infraestructura. Biblos: Buenos Aires.

Midaglia, C., \& Antía, F. (2017). Bienestar y protección social en América Latina. Abordajes conceptuales y metodológicos para el Mercosur. Paraguay: Instituto Social del Mercosur.

Mora, E., \& Medina, L. (2011). La Globalización del Cuidado y sus Cadenas: Un Estudio de Caso Psicoperspectivas, 10(2), 109-133.

Moreno, A. (2007). Modelos familiares y empleo de la mujer en el Estado de bienestar español. Madrid: Fundación Alternativas.

Moreno, S. (2015). The gendered division of housework time: Analysis of time use by type and daily frequency of household tasks. Time \& Society, 26(1), 3-27. 
Moreno, S. et al. (2013). El trabajo de cuidados en los regímenes de bienestar:¿más dependencia y menos profesionalidad? Actas del IV Congreso de la Red Española de Política Social. U. de Alcalá.

Moreno, S. (2009). Uso del tiempo, desigualdades sociales y ciclo de vida. Política y Sociedad, 46(3), 191-202.

Ortiz-Monera, R., Di Nella, D., \& Almeda, E. (2016). One-Parent Families in Spain: Exclusions and Social Networks. In M. Motapanyane (Ed.), Motherhood and Lone/Single Parenting: A 21 st Century Perspective (243-264). Bradford-Canada: Demeter Press.

Oso, L., \& Parella, S. (2012). Inmigración, género y Mercado de trabajo: una panorámica de la investigación sobre la inserción Laboral de las mujeres inmigrantes en España. Cuadernos de Relaciones Laborales, 30(1).

Parella, S. (2003). Mujer, inmigrante y trabajadora: la triple discriminación. Barcelona: Anthropos.

Parkman, A. (2004). Bargaining over housework: The frustrating situation of secondary wage earners. American Journal of Economics and Sociology, 63(4), 765-794.

Pérez Orozco, A. (2006). Amenaza tormenta: La crisis de los cuidados y la reorganización del sistema económico. Revista de Economía Crítica, 5, 7-37.

Pinto, K., \& Coltrane, S. (2009). Divisions of labor in Mexican origin and Anglo families: Structure and culture. Sex Roles, 60(7-8), 482-495.

Rajivan, A. K. (1999). Policy Implications for Gender Equity: The India Time Use Survey 1998-1999. Ahmedabad: International Seminar on Time Use Surveys.

Ramos R. (2011). Más allá de las cifras: la dimensión teórica y cualitativa del cuidado. In M.A. Durán (Dir.), El trabajo del cuidado en América Latina y España (75-87). Madrid: Fundación Carolina-CEALCI. Work documents, Nr. 54.

Ramos, R. (1990). Cronos Dividido. Uso del tiempo y desigualdad entre mujeres y hombres en España. Madrid: Ministerio de Asuntos Sociales, Instituto de la Mujer.

Rizavi, S. S., \& Sofer, C. (2010). Household division of labour: is there any escape from traditional gender roles?. Cahiers de la maison des sciences economiques. L'Atelier Paris1-Le Caire: Cairo.

Rodríguez, C. (2015). El trabajo de cuidado no remunerado en Argentina: un análisis desde la evidencia del Módulo de Trabajo no Remunerado. In Documentos de trabajo Políticas públicas y derecho al cuidado, 2. ELA - Equipo Latinoamericano de Justicia y: Género.

Rogero, J. (2010). Los tiempos del cuidado: el impacto de la dependencia de los mayores en la vida cotidiana de sus cuidadores. Madrid: Ministerio de Sanidad y Política Social- Imserso. Col. Estudios.

Salazar, O. (2016). The fragility of gender equality policies in Spain. Social Sciences., 5(2), 1-17.

Sayer, L. (2010). Trends in housework. In J. Treas \& S. Drobnic (Eds.), Dividing the domestic: Men. women and household work in cross-national perspective. Stanford: Stanford University Press.

Sevilla-Sanz, A., Giménez-Nadal, J., \& Fernández, C. (2010). Gender roles and the division of unpaid work in Spanish households. Feminist Economics, 16(4), 137-184.

Tobío, C. (2012). Cuidado e identidad de Género. De las madres que trabajan a los hombres que cuidan. Revista Internacional de Sociología, 70(2), 399-422.

Torns, T. (2008). El trabajo y el cuidado: cuestiones teórico metodológicas desde la perspectiva de género. Empiria. Revista de Metodología de las ciencias sociales, 15, 53-73.

Torns, T. (2001). El tiempo de trabajo de las mujeres: entre la invisibilidad y la necesidad. In C. Carrasco (Ed.), Tiempos, trabajos y género. Barcelona: Publicacions de la Universitat de Barcelona.

Torns, T. (2004). Las Políticas de tiempo: un reto para las políticas del estado del bienestar. Trabajo: Revista andaluza de Relaciones Laborales, 13, 145-164.

Treas, J., \& Drobnic, S. (2010). Dividing the domestic: men, women and household work in crossnational perspective. Stanford: Stanford University Press. 
United Nations Statistics Division. (2005). Guide to Producing Statistics on Time Use: Measuring Paid and Unpaid Work. Series F, 93.

World Economic Forum. (2018). The Global Gender Gap Report 2018. Cologny/Geneva: World Economic Forum.

Yu, J., \& Xie, Y. (2014). The varying display of 'gender display'. Chinese Sociological Review, 2(44), 5-30.

Open Access This chapter is licensed under the terms of the Creative Commons Attribution 4.0 International License (http://creativecommons.org/licenses/by/4.0/), which permits use, sharing, adaptation, distribution and reproduction in any medium or format, as long as you give appropriate credit to the original author(s) and the source, provide a link to the Creative Commons licence and indicate if changes were made.

The images or other third party material in this chapter are included in the chapter's Creative Commons licence, unless indicated otherwise in a credit line to the material. If material is not included in the chapter's Creative Commons licence and your intended use is not permitted by statutory regulation or exceeds the permitted use, you will need to obtain permission directly from the copyright holder.

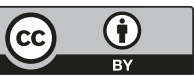

